\title{
6. Impact of state-civil society co-management contracts on water supply in rural India: evidence from a natural experiment ${ }^{1}$
}

\author{
Namrata Chindarkar, Yvonne Jie Chen and \\ Dennis Wichelns ${ }^{2}$
}

\section{INTRODUCTION}

In recent years, there has been an emergence of governments contracting with civil society organizations (CSOs) in both developed and developing countries. Governments routinely contract out public services such as sanitation, public infrastructure maintenance, healthcare, and social services (Smith 2007). This is a significant policy shift, as CSOs which previously were called upon primarily to remedy government failures are now seen as competent agents and providers of public services (Bryce 2006). As governments increasingly rely on non-state actors to provide public services and achieve public policy goals, hybrid models of contracts are evolving, especially so in the domains of environment and sustainable development policy (Steurer 2013). Co-management is one such hybrid model in which government and civil society actors aim to achieve common objectives, supply public services jointly, or manage common pool resources through formal contracts or agreements (Steurer 2013). Co-management goes beyond mere legal arrangements of power sharing between the state and civil society actors and involves mapping of essential management tasks and problems to be solved and capacity-building of the beneficiaries or local communities for enhancing their problem-solving skills (Carlsson and Berkes 2005).

Empirical evidence regarding service outcomes of government-CSO contracts in developing countries is largely missing in the literature. Specifically, there is no systematic evaluation of the effectiveness of co-management contracts on water services delivery outcomes. Alexander et al. (2015) compare selected measures of household welfare in villages in which a CSO 
had installed new wells to provide drinking water, with villages that had not received that intervention. Some measures of welfare were improved in the treatment villages, but there was no formal co-management contract. There was also no capacity-building of the community through training on how to maintain or repair the village handpumps post-intervention. Thus, the household benefits of village well installation were not sustained. James (2004) and Hutchings et al. (2017) examine a rich set of case studies on rural water management in India. They find that there is increasing engagement of community-based CSOs in rural water management and more importantly there is growing government recognition of CSOs being legitimate partners and service providers. However, they do not assess whether there is a consequent improvement in water management outcomes owing to greater engagement with CSOs or co-management.

In this study, we attempt to address this gap by evaluating a governmentCSO co-management contract to service village water handpumps. Providing adequate access to water in rural communities remains a challenge across much of India. Only 35 percent of rural households have access to drinking water within their premises. About 43 percent have access near their premises (within 500 meters) and 22 percent have access away from their premises (beyond 500 meters) (Census of India 2011a). Several state water authorities in India have endeavored to improve access to water in rural areas by installing large numbers of village handpumps, facilitated by the development of indigenous, low-cost handpump technology (Baumann and Furey 2013). ${ }^{3}$ However, water authorities have found it increasingly difficult to maintain the large number of handpumps, resulting in an operations and maintenance (O\&M) model, in which governments contract out repair and maintenance services to non-state actors such as private contractors and CSOs (World Bank 2016).

Our study exploits a unique setting in which village water handpump repair contracts are awarded to CSOs and private contractors (non-CSO) by the public water authority through a competitive tendering process. Our study setting is the Sabarkantha district in Northern Gujarat, India, a semi-arid, water stressed region. Most of the villages in the district lack piped water connections and depend largely on handpumps to access groundwater. The handpumps need regular maintenance, as mud, foreign particles, and the salinity of groundwater deteriorate the machinery over time. When a handpump breaks down, households that rely on it for water need to turn to alternative water sources or travel to a further handpump to collect water. Therefore, the quality and efficiency of the repair and maintenance services provided by contractors affect the average time a household spends collecting water.

We surveyed community handpump end-users living in two adjacent sub-districts in Sabarkantha, namely Bayad and Dhansura, which are serviced by two different contractors. In 2013, the contract in Bayad was given to 
the Self-Employed Women's Association (SEWA). The unique attributes of SEWA are, first, it is a membership-based trade union of self-employed women and India's largest CSO. Second, it makes access to water, management of water resources, and maintenance of water infrastructure salient through various initiatives under its 'water campaign.' And third, the distinguishing feature of SEWA contractors is that its handpump repair team comprises entirely of women members, known locally as 'barefoot mechanics.' The contract in Dhansura was given to a private contractor (hereafter referred to as non-SEWA contractor). These service contracts were assigned through a tendering process as discussed in further detail in the study design and methods section. The competitive process of allocating tenders thus provides a natural experiment setting and generates geographic variation in service quality in Bayad and Dhansura, which we exploit to identify the effect of government-CSO co-management of handpump repair services. We take several steps to ensure that households residing in these two sub-districts are otherwise similar, in the absence of SEWA service contractors.

Our study contributes to the current literature on government-CSO co-management of water services in several ways. To our knowledge, this is the first study that provides empirical evidence on the management and maintenance of village water handpumps differentiated on the basis of the nature of the contractual relationship. Our survey provides detailed evidence on the quality of handpump repair services delivered by SEWA-trained contractors and their private counterparts in neighboring villages. We examine variation in the amount of time taken by contractors to repair broken handpumps, because delays in handpump repair impose substantial costs on households that must invest time and effort in obtaining water from alternative sources. The imposed costs of delayed repairs fall largely on women, who bear the primary burden of collecting water for their households. Our survey addresses a critical gap in previous studies by collecting data on seasonal variation in water collection time. In many rural areas, water collection time can differ significantly in the dry and wet seasons, with variation in the availability of surface water and groundwater resources. We argue that the variation in service quality induced by the two types of contractors is causally related with the time that households spend collecting water in the two sub-districts.

Our results indicate that SEWA contractors provide better quality service than non-SEWA contractors. Specifically, SEWA service significantly reduces water collection time in both the dry and wet seasons and reduces handpump repair time, thus further reducing the cost of water collection. Our survey data do not allow us to decompose whether the observed effects are due to SEWA's organizational identity, managerial capacity, political capacity, or the individual technical capacity of SEWA's female technicians. Limited qualitative data indicate that SEWA contractors have unique motivations to serve the commu- 
nity, especially women. We therefore interpret our results as a composite effect of government-CSO co-management of handpump repair services including the motivations of the CSO contractors.

The remainder of the study proceeds as follows. The next section discusses the conceptual framework we use to analyze co-management followed by the background information on the co-management setting. We then describe the study design and explain the empirical strategy used in this study. The following section presents and discusses the results. Finally, the study concludes by summarizing the key findings and reflecting on the policy takeaways.

\section{CO-MANAGEMENT IN PUBLIC SERVICE DELIVERY: A CONCEPTUAL FRAMEWORK}

Co-management, as an alternative arrangement in public service delivery, is defined as a collaborative arrangement between the government and civil society sector to produce and deliver public service together. In this arrangement, CSOs are mandated with the production of public services in partnership with other public or business organizations (Brandsen and Hout 2006; Brandsen and Pestoff 2006).

In recent years, there has been an observable trend of governments contracting out services to CSOs in both developed and developing countries. Several explanations for the increase in government-CSO co-management contracts appear in the literature. First, from a principal-agent theory perspective, governments and CSOs have closely aligned and converging goals, which minimizes agency problems and consequently better serves public interests (Bryce 2006; Slyke 2006; Witesman and Fernandez 2012). Second, from a normative perspective, there is widespread recognition that CSOs have better knowledge of the needs and priorities of the communities they serve (Siddiqi and Oever 1998; Khanom 2012). CSOs also bring about equity and accountability in providing services to the community, while increasing participation and empowerment of community members (Brinkerhoff 2002). Third, entering in a co-management relationship with CSOs is viewed as a form of good governance, particularly in democratically governed developing countries (Haque 2004). They bring legitimacy to democratic governments through their emphasis on decision-making through participation and consultation. And last, CSOs are seen to enhance the efficiency, effectiveness, and responsiveness of governments (Brinkerhoff 2002; Haque 2004). As CSOs typically serve at the grassroots level, they are considered instrumental in resolving the last mile problem and ensuring that public programs and services are accessible to all. It is also argued that CSOs are often better and more innovative implementers than the government (Khanom 2012). 
Contemporary literature on water governance supports co-management contracts which explicitly recognize the roles and contributions of CSOs. It is argued that involving CSOs brings in greater inclusion of local expertise, interests, and values in water management (Naiga, Penker, and Hogl 2017; Taylor and Sonnenfeld 2017). In many developing countries including India, there is a move towards 'community management plus' and 'professional community-based management' models of rural water management. Under both models, community-based CSOs enter into formal contracts with the government and support rural water management functions such as O\&M of public water infrastructure, water quality testing, and community mobilization in identifying water needs and conflicts. CSOs are expected to work in accordance with agreed standards set by the government and with greater transparency and accountability. The difference between the two models is that 'professional community-based management' involves greater professionalism on part of the CSOs such as following good business and accounting practices, and training and hiring paid staff to perform set functions (Hutchings et al. 2017).

The key dimension determining the effectiveness of government-CSO relationships is capacity (Howlett and Ramesh 2016). Levels of capacity include analytical or technical competence, managerial competence, and political competence. Technical capacity refer to concrete skills to be able to conduct the task at hand or solve the assigned problem. Managerial capacity comprises leadership, coordination, staffing, funding, and so on within the organization. And political capacity involves understanding the needs of the beneficiaries being served as well as other stakeholders, and the ability to build trust and legitimacy. Success of co-management would likely depend on the ways in which actors involved in the governance relationship either complement or supplement these capacities.

Two other dimensions are said to determine the effectiveness of government-CSO contractual relationships - mutuality and organization identity (Brinkerhoff 2002). Mutuality refers to interdependence between partners and entails commitment to shared goals and objectives. Organizational identity refers to the distinctive and enduring features of the partnering organizations. Brinkerhoff (2002) argues that for government-CSO relationships to succeed, organizational identity needs to be maintained and not surrendered over the duration of the contract. This implies that the mission and core values of an organization remain consistent, and its comparative sectoral advantages are sustained. In a co-management relationship, one would expect there to be a high degree of both mutuality and organizational identity, similar to what Brinkerhoff (2002) terms as a 'partnership.'

There is some empirical literature from developed countries on the differences in service outcomes, taken as a measure of success, when governments 
contract out public services to CSOs, versus when services are contracted out to private organizations. Evidence suggests there is no significant difference in performance between non-profit and for-profit contractors in terms of cost, quality of work, responsiveness to government requirements, legal compliance, or customer satisfaction. However, public officials still trust non-profit contractors more than for-profit contractors (Witesman and Fernandez 2012). There is some evidence describing heterogeneity in service outcomes within different types of non-profits, as a result of their organizational makeup and identity (Knox, Blankmeyer, and Stutzman 2006). Evidence suggests also that even when consumers or end-users are not necessarily aware of the incorporation status of their service providers, they are more likely to trust and patronize the services of non-profits (Handy et al. 2010).

\section{THE CO-MANAGEMENT SETTING: O\&M OF VILLAGE WATER HANDPUMPS IN RURAL GUJARAT}

In the arid and semi-arid regions of Gujarat, including the Sabarkantha district, surface water is scarce and households largely depend on groundwater. Access is achieved mainly through community handpumps, as most households in the district do not have piped water connections. Recognizing the importance of handpumps, the Gujarat Water Supply and Sewerage Board (GWSSB) has installed nearly 10,000 handpumps across the state to improve village water access (Panda 2005). The handpumps require regular maintenance as the mechanical parts deteriorate over time due to salinity and foreign particles, and also because they are shared by several households. Therefore, even with the installation of more handpumps, access to water can be unreliable if they are not serviced on a regular basis. It is administratively difficult for GWSSB to monitor and conduct handpump maintenance across the state. Thus, it invites tenders and contracts out the maintenance work on an annual basis. Contracts are awarded for each sub-district in Sabarkantha, such that within the larger district (Sabarkantha) several different contractors may be engaged (one contractor in each sub-district). A single contractor may or may not be awarded contracts for different sub-districts.

SEWA, a trade union of self-employed women established in 1972, has about 600,000 members in the state of Gujarat. It runs the 'Women, Water, and Work Campaign,' whose mission is to provide rightful access to clean drinking water to every rural household. To achieve this, SEWA mobilizes and trains its women members to repair village water handpumps as a way to create an income-generating opportunity for them and also to improve the quality of maintenance service. In the Sabarkantha district, our study setting, SEWA has been training women to repair handpumps since 1999. To bid for 
GWSSB tenders, SEWA established a trust called 'Khedut Mandal' (Farmers' Association) in which all the repairwomen have a direct stake.

GWSSB's need to decentralize maintenance of handpumps and SEWA's unique organizational identity, mission, and capacity converged in late-1999, when SEWA won its first contract in two sub-districts of Sabarkantha-Bayad and Dhansura. The GWSSB-SEWA relationship goes beyond mere contractual arrangements of delegating O\&M tasks. SEWA repairwomen initially lacked the technical capacity to bid for the tenders. However, by leveraging its managerial capacity to coordinate efforts at various levels including at the very grassroots level and political capacity to conduct dialogues and negotiations, SEWA was able to convince GWSSB that women can be capable technicians if provided adequate training. GWSSB assisted in conducting the training sessions and ensuring that its repair and maintenance standards are met. A typical training session spans over three days and consists of theoretical understanding of the functioning of handpumps and practical sessions where prospective SEWA repairwomen can assist on an actual repair job (Chen and Chindarkar 2017). GWSSB thus invested substantial resources into capacity-building of SEWA repairwomen, which enabled them to bid for the tenders and also successfully secure contracts. As shown in Table 6.1, SEWA won contracts to service handpumps in all the villages in the Bayad and Dhansura sub-districts through 2003, except in the year 2000. Since then, however, SEWA has only won contracts in the Bayad sub-district. The most recent service contract awarded to SEWA prior to our survey was in September 2013 for Bayad sub-district. SEWA also utilizes its managerial and political capacity to hold regular dialogues with GWSSB to make the needs of the community known to decision-makers (Panda 2005). The nature of the GWSSB-SEWA relationship thus resembles that of a co-management contract. To our knowledge, these characteristics are not shared by contracts between GWSSB and the private contractors. ${ }^{5}$

\section{STUDY DESIGN AND METHODS}

We follow a study design similar to Cattaneo et al. (2009) by exploiting the geographic variation in service quality. Cattaneo et al. (2009) use adjacent twin cities that are administratively part of a single urban area and share similar characteristics to study the effects of a housing improvement program in Mexico using cross-sectional data. Similarly, we construct treatment and control groups generated by the handpump repair and maintenance tendering process in two adjacent sub-districts that are administratively part of the same district and state, and share similar characteristics.

It is important to understand the tendering process for the handpump repair and maintenance contracts as it forms the foundation of our empirical strategy. 
Table 6.1 Chronology of SEWA handpump repair contracts in Bayad and Dhansura

\begin{tabular}{|c|c|c|}
\hline Date of contract & Bayad & Dhansura \\
\hline Sep 271999 & Yes & Yes \\
\hline 2000 & No & No \\
\hline Oct 032001 & Yes & Yes \\
\hline Dec 312002 & Yes & Yes \\
\hline Nov 142003 & Yes & Yes \\
\hline Jan 292004 & Yes & No \\
\hline 2005 & No & No \\
\hline Feb 222006 & Yes & No \\
\hline 2007 & No & No \\
\hline 2008 & No & No \\
\hline 2009 & No & No \\
\hline Nov 042010 & Yes & No \\
\hline Dec 072011 & Yes & No \\
\hline May 302012 & Yes & No \\
\hline Sep 032013 & Yes & No \\
\hline 2014 & Yes & No \\
\hline 2015 & Yes & No \\
\hline
\end{tabular}

Source: Self-Employed Women's Association (SEWA) internal document.

We argue that the process generates random variation in service quality across the sub-districts. Every year, GWSSB invites contractors to submit tenders for the handpump repair and maintenance contracts. The submission process was offline prior to 2006, but since then all tender submissions must be made through an online e-procurement system. Tender advertisements are placed in leading regional newspapers such as the 'Divya Bhaskar' and also posted on the e-procurement system website, www.nprocure.com. Details about the contract, such as the geographical and technical scope of the work, estimated cost value, tender fees, tender submission deadline, and a web link to the e-procurement submission system are clearly provided in the advertisement. Applicants can access pertinent documents either online via the e-procurement system or offline. However, completed forms and supporting documents must be submitted online. After the documents have been submitted, applicants must pay the tender fees through an online gateway facilitated by major nationalized and private banks. Only upon the approval of the online payment, is the tender included in the competition. 
The e-procurement system is encrypted to ensure security of the submitted tenders. Each contract has a 'Tender Opening Committee' nominee, who is authorized to access and open all submissions on a specified date and time. Incomplete, erroneous, or fabricated submissions are promptly rejected. Factors that determine whether a submitted tender is successful are: (1) the quoted price and how closely it matches GWSSB estimates, (2) whether the contractor is willing to bear or share the cost of incidentals and transportation for the repair workers, (3) the value-added services provided, such as the number of overhauls per handpump (regular maintenance not connected with break downs), and (4) prior service record if any. To prevent contractors from resorting to backdoor negotiations to get their tenders approved, an annual audit of contracts is conducted. Auditors have the authority to reject a submitted or approved tender if they suspect that the process was not fair and transparent. The process of securing a contract is therefore free from structural bias, due to the tendering procedures and monitoring by the auditors. ${ }^{6}$

We take several steps to ensure that households in the two sub-districts comprise appropriate treatment and control groups for our study. First, we show that the two sub-districts, Bayad and Dhansura, share very similar geographic and socio-economic characteristics. Second, we restrict our end-users sample exclusively to households that depend on GWSSB handpumps as their main source of water, as these are the households directly affected by services of the handpump contractors. We use GIS coordinates to record the precise distance between the GWSSB handpump and each household to reduce potential reporting and measurement error. We discuss sub-district characteristics and sampling strategy in the remainder of this section.

\section{Comparison of Bayad and Dhansura}

We collected the data for this study in Bayad and Dhansura during December 2013. Bayad and Dhansura are adjacent sub-districts that administratively fall under the jurisdiction of the Sabarkantha district (Figure 6.1). While village-level governments are formed to overlook day-to-day work, key policy decisions pertaining to agriculture, infrastructure, industry, health, education, and social welfare are taken by the district- and state-level governments. Therefore, the two sub-districts are exposed to the same policy decisions. As observed in Table 6.2, although Bayad is larger and more populous, the geographical and socio-economic characteristics of the two sub-districts are comparable. In particular, they share similar rainfall, temperature, and land gradients, which are important factors determining access to groundwater. ${ }^{7}$ Average annual rainfall is $838 \mathrm{~mm}$ in Bayad and $894 \mathrm{~mm}$ in Dhansura. Average annual temperature is about 27 degrees Celsius in both sub-districts. Both sub-districts are on the North Gujarat plain with Bayad at 106 meters above mean sea-level and Dhansura at 129 meters above mean sea-level. 
Further, both sub-districts are in the North Gujarat Agroclimatic Zone as classified by the Department of Agriculture and Cooperation, Government of India, which implies that they also share similar soils and cropping patterns (Department of Agriculture and Cooperation 2015). Most importantly, focus group interviews with villagers and village key informants in the sampled villages suggested no presence of CSO contractors other than SEWA. ${ }^{8}$

Given the observed similarity in sub-district level characteristics that may affect outcome variables, the bias resulting from excluding those characteristics in the empirical specifications can be assumed to be negligible. Nevertheless, we control for village-level characteristics to mitigate some of the differences, such as population size.

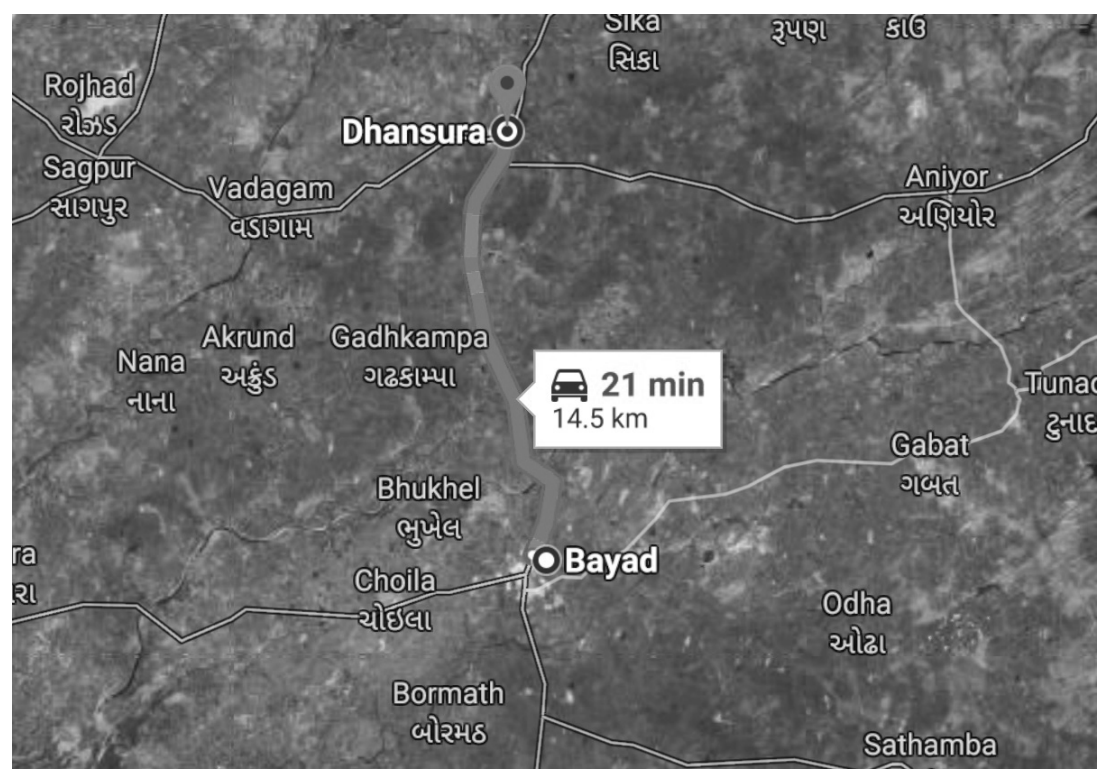

Source: Google Maps (2019).

Figure 6.1 Location of the Bayad and Dhansura sub-districts in the western Indian State of Gujarat

\section{Sampling Strategy}

SEWA provided a list of all villages in which it services handpumps, from which we randomly selected a sample of SEWA serviced villages. Villages in Dhansura sub-district serviced by non-SEWA contractors were randomly drawn from the census. We selected a total of 20 villages - 10 SEWA serviced and 10 serviced by 
Table 6.2

Comparison of Bayad and Dhansura sub-districts

\begin{tabular}{lll}
\hline & Bayad & Dhansura \\
\hline Geographical characteristics & 560 & 391 \\
Total area (square kilometers) & 838 & 894 \\
Annual average rainfall (mm) & 27 & 27 \\
Annual average temperature (Celsius) & 106 & 129 \\
Elevation (meters) & & \\
& & \\
Demographic characteristics & 121 & 72 \\
Number of villages & 188,505 & 106,733 \\
Total population & 48 & 43 \\
Proportion of working population & \\
Literacy rate & 67 & 66 \\
& & \\
Socio-economic characteristics & 83 & \\
\% electricity as primary source of lighting & & \\
\% improved drinking water source & & 91 \\
\% banking services & 99 & 99 \\
\% landline telephones & 50 & 53 \\
\% mobile phones & 2 & 31 \\
\hline
\end{tabular}

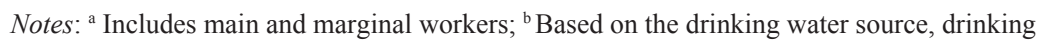
water supply has been classified as 'improved' or otherwise. If the household has access to drinking water supplied from a tap or a handpump/tube well situated within or outside the premises it is considered as having access to 'improved drinking water source.' The concept of improved drinking water is state-specific.

Source: Census of India (2011b); Gujarat State Disaster Management Authority (2012).

non-SEWA contractors. For selecting the end-user households, we first mapped and geocoded all GWSSB handpumps in the selected villages. This was done with the assistance of the village local government (Panchayat). The selection criterion for end-user households was that they must depend on a GWSSB handpump as their main source of water. We randomly selected 10 households in each village at varying distances from the GWSSB handpumps they mainly use. We therefore exclude households that may have their own private handpumps, which do not fall under the GWSSB contract terms. We geocoded each household to accurately compute the distance between the household and the GWSSB handpump they mainly use. The geographic locations of the sampled households are shown in Figure 6.2. Blue dots depict households located in Dhansura sub-district and yellow dots depict households in Bayad sub-district. Three pink dots represent the locations of sub-district and district local government offices. In addition to 
the households, we interviewed two key informants in each village to collect village-level data and information describing the overall quality of water service delivery. These key informants were either Panchayat officials or public servants such as teachers and health workers living and working in the village. ${ }^{9}$

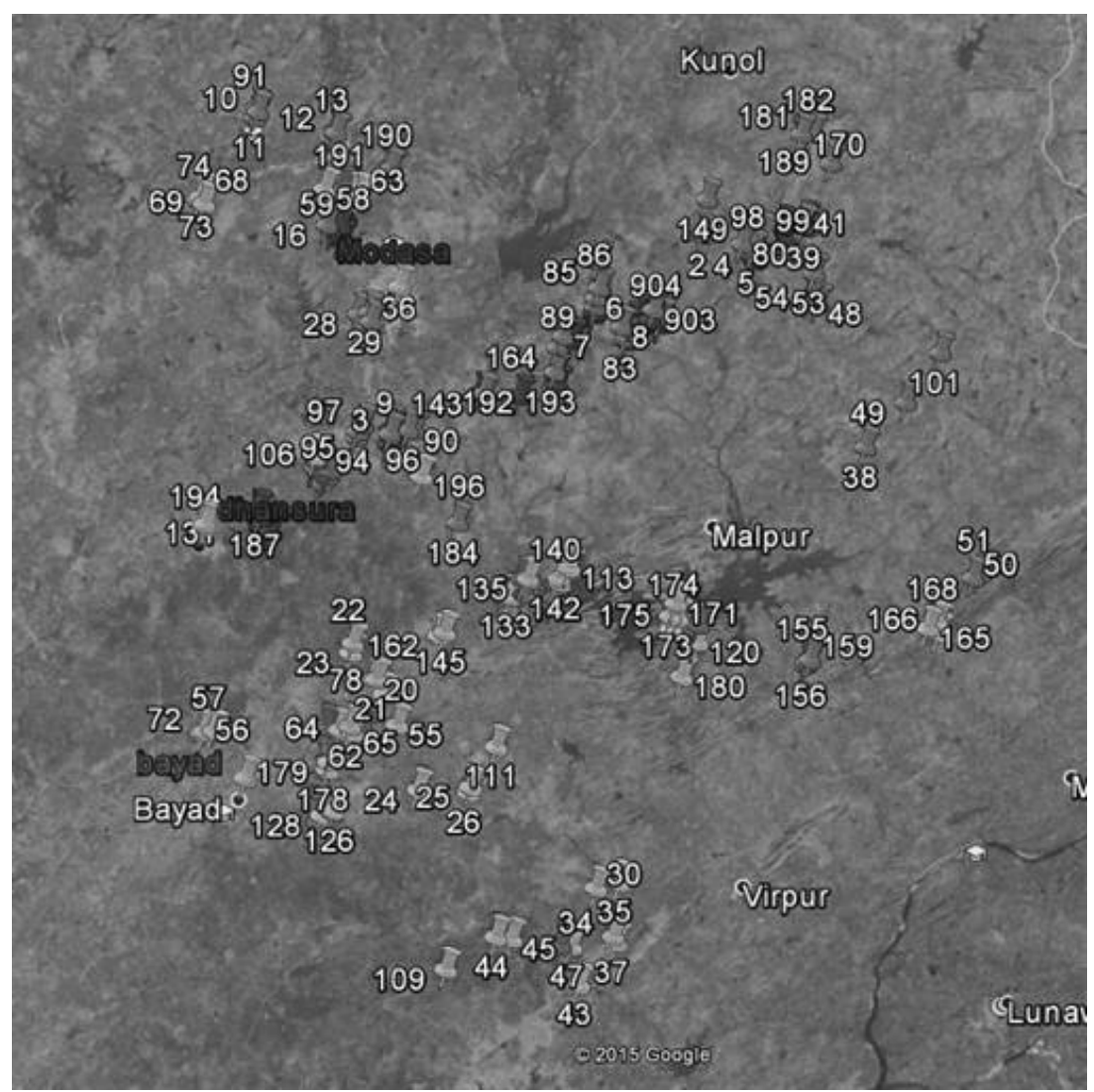

Source: Author's analysis.

Figure 6.2 Village and household locations

\section{Summary Statistics and Empirical Strategy}

Ideally, we would compare the pre-treatment end-user household characteristics between the two sub-districts to assess the balance between control and treatment groups. However, the pre-treatment household-level data are not available. Therefore, we follow the same strategy as Cattaneo et al. (2009) and compare 
variables collected by our survey that are relatively exogenous to the contracting process. Among the variables compared in Table 6.3 Panel B, four are significantly different at the 10 percent level. All other variables are not statistically

Table 6.3 Summary statistics for households served by SEWA and non-SEWA contractors

\begin{tabular}{|c|c|c|c|}
\hline & \multicolumn{2}{|l|}{ Mean } & \multirow{2}{*}{$\begin{array}{l}\text { Difference } \\
\text { Non-SEWA } \\
\text { - SEWA }\end{array}$} \\
\hline & $\begin{array}{l}\text { Non-SEWA } \\
\text { serviced }\end{array}$ & SEWA serviced & \\
\hline \multicolumn{4}{|l|}{$\begin{array}{l}\text { Panel A: Individual Characteristics } \\
\text { (Person most responsible for collecting } \\
\text { water) }\end{array}$} \\
\hline Age (years) & $\begin{array}{l}35.89 \\
(1.130)\end{array}$ & $\begin{array}{l}34.55 \\
(1.030)\end{array}$ & $\begin{array}{l}1.34 \\
(1.529)\end{array}$ \\
\hline Education (years) & $\begin{array}{l}2.99 \\
(0.221)\end{array}$ & $\begin{array}{l}2.90 \\
(0.208)\end{array}$ & $\begin{array}{l}0.09 \\
(0.304)\end{array}$ \\
\hline Gender $($ female $=1)$ & $\begin{array}{l}0.970 \\
(0.017)\end{array}$ & $\begin{array}{l}0.980 \\
(0.014)\end{array}$ & $\begin{array}{l}-0.010 \\
(0.022)\end{array}$ \\
\hline $\mathrm{N}$ & 165 & 185 & \\
\hline Panel B: Household Characteristics & & & \\
\hline Caste (Head of household) & $\begin{array}{l}0.770 \\
(0.042)\end{array}$ & $\begin{array}{l}0.850 \\
(0.036)\end{array}$ & $\begin{array}{l}-0.080 * \\
(0.055)\end{array}$ \\
\hline Household members $<=17$ years & $\begin{array}{l}1.680 \\
(0.167)\end{array}$ & $\begin{array}{l}1.970 \\
(0.152)\end{array}$ & $\begin{array}{l}-0.290 * \\
(0.226)\end{array}$ \\
\hline Asset index & $\begin{array}{l}29.440 \\
(1.246)\end{array}$ & $\begin{array}{l}27.940 \\
(1.210)\end{array}$ & $\begin{array}{l}1.500 \\
(1.737)\end{array}$ \\
\hline Farm Income ( 1,000 rupees) & $\begin{array}{l}23.35 \\
(25.83)\end{array}$ & $\begin{array}{l}21.05 \\
(32.19)\end{array}$ & $\begin{array}{l}2.303 \\
(4.147)\end{array}$ \\
\hline Size of agricultural land (bighas) & $\begin{array}{l}4.786 \\
(0.593)\end{array}$ & $\begin{array}{l}4.375 \\
(0.366)\end{array}$ & $\begin{array}{l}0.411 \\
(0.698)\end{array}$ \\
\hline No alternative source of water & $\begin{array}{l}0.370 \\
(0.049)\end{array}$ & $\begin{array}{l}0.280 \\
(0.045)\end{array}$ & $\begin{array}{l}0.090 * \\
(0.066)\end{array}$ \\
\hline Distance to GWSSB handpump (km) & $\begin{array}{l}2.161 \\
(0.521)\end{array}$ & $\begin{array}{l}2.667 \\
(0.628)\end{array}$ & $\begin{array}{l}-0.506 \\
(0.816)\end{array}$ \\
\hline Own electric water pump & $\begin{array}{l}0.050 \\
(0.022)\end{array}$ & $\begin{array}{l}0.120 \\
(0.033)\end{array}$ & $\begin{array}{l}-0.070 * \\
(0.039)\end{array}$ \\
\hline $\mathrm{N}$ & 100 & 100 & \\
\hline
\end{tabular}

Notes: One Indian rupee $=0.015$ US dollars (November 10, 2017). One bigha (in Gujarat) $=0.4$ acres, or 0.16 hectares. The asset index is measured as a sum score of 30 individual assets. 
different. In Table 6.3 Panel B we observe that SEWA-serviced households have fewer alternative sources of water, have more dependents, and a higher proportion are from lower castes. There are no significant differences in the average age, education levels, and gender of the person most responsible for collecting water for the household. Further, there is no significant difference in the distance to GWSSB handpumps between SEWA serviced and non-SEWA serviced villages. None of the village-level characteristics are statistically different between SEWA and non-SEWA serviced villages (Table 6.4 Panel B). These villages have similar numbers of households and areas of irrigated land. They also have similar levels of access to piped water, well water, primary schools, and primary health centers.

Table 6.4 Summary statistics for village key informants and reported village characteristics

\begin{tabular}{|c|c|c|c|}
\hline & \multicolumn{2}{|l|}{ Mean } & \multirow{2}{*}{$\begin{array}{l}\text { Difference } \\
\text { Non-SEWA - SEWA }\end{array}$} \\
\hline & Non-SEWA serviced & SEWA serviced & \\
\hline \multicolumn{4}{|l|}{ Panel A: } \\
\hline \multicolumn{4}{|l|}{ Key Informant Characteristics } \\
\hline \multirow[t]{2}{*}{ Age (years) } & 43.110 & 43.590 & -0.480 \\
\hline & $(11.32)$ & $(12.290)$ & $(3.741)$ \\
\hline \multirow[t]{2}{*}{ Gender $($ female $=1)$} & 0.167 & 0.182 & -0.015 \\
\hline & $(0.383)$ & $(0.395)$ & $(0.124)$ \\
\hline \multirow[t]{2}{*}{ Education (years) } & 5.500 & 5.455 & 0.046 \\
\hline & $(2.065)$ & $(2.464)$ & $(0.716)$ \\
\hline \multicolumn{4}{|l|}{ Panel B: } \\
\hline \multicolumn{4}{|l|}{ Reported Village Characteristics } \\
\hline \multirow[t]{2}{*}{ Number of households } & 190.560 & 252.720 & 62.17 \\
\hline & $(46.940)$ & $(27.580)$ & $(57.66)$ \\
\hline \multirow[t]{2}{*}{ Lowest household income (rupees) } & 13111.100 & 10613.600 & 2497.50 \\
\hline & $(4689.00)$ & $(6229.600)$ & $(1727.9)$ \\
\hline \multirow[t]{2}{*}{ Irrigated land size (bighas) } & 186.100 & 199.300 & -13.210 \\
\hline & $(69.78)$ & $(138.200)$ & $(33.750)$ \\
\hline \multirow[t]{2}{*}{ Access to piped water } & 0.444 & 0.318 & 0.126 \\
\hline & $(0.511)$ & $(0.477)$ & $(0.158)$ \\
\hline \multirow[t]{2}{*}{ Access to well water } & 0.389 & 0.455 & -0.066 \\
\hline & $(0.502)$ & $(0.510)$ & $(0.161)$ \\
\hline $\mathrm{N}$ & 20 & 20 & 40 \\
\hline
\end{tabular}

Notes: One Indian rupee $=0.015$ US dollars (November 10, 2017). One bigha (in Gujarat $)=0.4$ acres, or 0.16 hectares. 
The summary statistics indicate that although households are somewhat different in the SEWA serviced and non-SEWA serviced sub-districts, the village-level water infrastructure is quite similar. Therefore, from the contractors' perspective, maintaining the handpumps in these two regions should involve very similar time and effort.

Our outcomes of interest consist of two sets of variables: the assessment of service quality and the time spent collecting water. As we have shown that both sub-district level and village-level characteristics between the control (Dhansura) and treatment (Bayad) households are almost identical, we believe it is very unlikely that any village or sub-district level unobservables would correlate with household location or with the outcome variables. To rule out bias generated by omitted variables at the household level, we control for a wide range of household characteristics, which include caste, household size, access to alternative water sources, and ownership of electric water pumps.

\section{Regression Model}

We use reduced form ordinary least squares (OLS) models to estimate the differences in the quality of handpump maintenance and repair by type of contract. We measure the quality of service at both the household level and the village level. For household-level measures we use the following regression equation

$$
Y_{i v}=\beta_{0}+\beta_{1} S E W A_{i v}+\beta_{2} X_{i v}+\beta_{3} H_{i v}+\beta_{4} G_{v}+\epsilon_{i v}
$$

where $Y_{i v}$ is the outcome measure of service quality for household $i$ in village $v$. We use three variables to operationalize service quality at the household level: (1) the reported frequency of pump breakdowns, (2) the time taken to fix a pump once it breaks down, and (3) the average time spent collecting water in both the dry and wet seasons. $S E W A_{i v}$ indicates whether a household lives in a village serviced by SEWA. $X_{i v}$ is a set of respondent characteristics including age, gender, and education. $H_{i v}$ is a set of household controls including caste of the household head, the number of household members aged 17 years and below, the size of agricultural land owned by the household, an asset index, whether the household owns an electric water pump, whether the household has alternative sources of water, and distance to the handpump used as the main source of water in kilometers, computed using GIS coordinates. $G_{v}$ is a set of village-level controls including village population, lowest village household income, and whether the village has access to piped water or well water. We estimate the time to collect water for the person most responsible for collecting water. 
We also estimate the differences in service quality by type of contract using information gathered from our key informant survey. We use the following reduced form OLS regression,

$$
Z_{i v}=\theta_{0}+\theta_{1} S E W A_{i v}+\theta_{2} X_{i v}+\theta_{3} G_{v}+u_{i v}
$$

where $Z_{i v}$ is the outcome measure of service quality for key informant $i$ in village $v$. SEWA $i v$ indicates whether the key informant lives in a village serviced by SEWA. $X_{i v}$ is a set of key informant individual characteristics including gender, age, education, and position. $G_{v}$ is a set of village controls including the same variables as described above.

As previously discussed, the geographic conditions are identical in the two sub-districts and no significant differences are observed across a wide range of village characteristics. However, as the household-level demographics reveal some differences between the SEWA serviced and non-SEWA serviced villages, there might still be endogeneity in the service provider variable $S E W A$. We reduce this bias by controlling for the household characteristics that are likely correlated with service quality outcomes.

\section{FINDINGS}

We report three sets of results with different control variables describing the relationship between the type of contract and the quality of handpump maintenance and repair. Table 6.5 reports the linear probability regression results on the effect of having a SEWA contractor on handpump service quality. Responses are based on the person who is most responsible for collecting water for the household. Our results indicate that on average there is no difference in having a frequent pump breakdown (more than once per month) between SEWA serviced and non-SEWA serviced households. However, SEWA serviced households have a higher probability of having the pump repaired within one week after it is broken. On average, SEWA serviced villages are 26 percentage points more likely to have a pump repaired within one week. The effect is more pronounced for pumps used by lower caste households. The result on lower caste households provides direct empirical support for the literature on the equity aspect of engaging community-based CSOs in rural water management and on them being more closely aligned with and having better knowledge of the needs and priorities of the communities they serve. Our key informant survey confirms these results. The proportion of handpumps repaired within one week is significantly higher in SEWA serviced villages (Table 6.6, Column 4), and SEWA serviced villages are less likely to 
Effect of SEWA service on quality of handpump maintenance and repair-household survey

\begin{tabular}{lllllll}
\hline & Probability of & \multicolumn{3}{c}{ Probability of } & \multicolumn{3}{c}{ Probability of } \\
\cline { 2 - 7 } & $\begin{array}{l}\text { Frequent } \\
\text { Pump Break }\end{array}$ & $\begin{array}{l}\text { Quick } \\
\text { Repair }\end{array}$ & $\begin{array}{l}\text { Frequent } \\
\text { Pump Break }\end{array}$ & $\begin{array}{l}\text { Quick } \\
\text { Repair }\end{array}$ & $\begin{array}{l}\text { Frequent } \\
\text { Pump Break }\end{array}$ & $\begin{array}{l}\text { Quick } \\
\text { Repair }\end{array}$ \\
\cline { 2 - 7 } & All households & & Upper caste households & Lower caste households \\
\cline { 2 - 7 } & $\mathbf{1}$ & $\mathbf{2}$ & $\mathbf{3}$ & $\mathbf{4}$ & $\mathbf{5}$ & $\mathbf{6}$ \\
\hline Baseline & -0.050 & 0.090 & $-0.137^{*}$ & 0.089 & 0.180 & 0.032 \\
regression & & & & & & \\
& $(0.071)$ & $(0.070)$ & $(0.078)$ & $(0.077)$ & $(0.132)$ & $(0.170)$ \\
N & 200 & 200 & 162 & 162 & 38 & 38 \\
R-Squared & 0.003 & 0.008 & 0.019 & 0.008 & 0.058 & 0.001 \\
Regression & -0.076 & $0.263 * * *$ & -0.076 & $0.302 * * *$ & -0.124 & $1.373 * * *$ \\
with & & & & & & $(0.368)$ \\
additional & $(0.082)$ & $(0.066)$ & $(0.093)$ & $(0.071)$ & $(0.296)$ & \\
controls & & & & & & 38 \\
N & 200 & 200 & 162 & 162 & 38 & 0.590 \\
R-Squared & 0.306 & 0.389 & 0.263 & 0.441 & 0.580 & \\
\hline
\end{tabular}

Notes: (a) Coefficients describe the effects of SEWA service, using the linear probability model in Equation 6.1; (b) Robust standard errors in parentheses; (c) 'Frequent pump break' takes the value 1 if a pump breaks at least once a month and 0 if less than once a month. 'Quick Repair' takes the value 1 if on average a broken pump gets repaired in less than a week and 0 if more than a week; (d) Baseline regression only includes one regressor that indicates whether or not a household is serviced by SEWA; (e) Regressions with additional controls also include: respondent age, gender, education level, household size, agriculture land size, caste of head of household, distance to the nearest GWSSB pump, whether the household has alternative water sources, whether the household owns an electric pump, village population, village lowest household income, and whether the village has access to piped water or well water; ${ }^{*} \mathrm{p}<0.1$, $* * \mathrm{p}<0.05, \mathrm{p}<0.001 * * *$.

experience frequent handpump breakdowns (Table 6.6, Column 1). However, this latter result is not supported by the household-level data.

Next, we examine the effect of the quality of handpump maintenance and repair on time spent collecting water. As the utilization and breakdown of handpumps differ by seasons, we report the results for both the dry and wet seasons. Table 6.7 shows that in SEWA serviced villages, on average, the person most responsible for collecting water spends 0.3 hours less per day collecting water in the dry season and 0.2 hours less per day in the wet season. Both results are highly statistically significant, regardless of model specification.

The results in Table 6.7 are obtained also when we control for distance to handpumps. As discussed earlier, the imposed cost of water collection involves distance, the frequency of pump breakdowns, and the time required to obtain repair. When a pump breaks down, households need to seek alternative water 
Table 6.6 Effect of SEWA service on quality of handpump maintenance and repair-key informant survey

\begin{tabular}{lllllll}
\hline & \multicolumn{5}{l}{ Pump Breakdowns } & \multicolumn{2}{l}{ Pumps Repaired within } & \\
\cline { 2 - 7 } & $\begin{array}{l}\text { Less } \\
\text { Frequent } \\
\text { Pump } \\
\text { Breakdowns }\end{array}$ & $\begin{array}{l}\text { Number } \\
\text { of Pump } \\
\text { Breakdowns }\end{array}$ & $\begin{array}{l}\text { One } \\
\text { Day }\end{array}$ & One Week & $\begin{array}{l}\text { Two } \\
\text { Weeks }\end{array}$ & $\begin{array}{l}\text { One } \\
\text { Month }\end{array}$ \\
\cline { 2 - 7 } & $\mathbf{1}$ & $\mathbf{2}$ & $\mathbf{3}$ & $\mathbf{4}$ & $\mathbf{5}$ & $\mathbf{6}$ \\
\hline Baseline & 0.338 & 1.071 & -0.152 & 0.116 & -0.055 & 0.113 \\
regression & & & & & & \\
& $(0.289)$ & $(1.399)$ & $(0.150)$ & $(0.115)$ & $(0.105)$ & $(0.096)$ \\
N & 40 & 40 & 40 & 40 & 40 & 40 \\
R-Squared & 0.035 & 0.015 & 0.027 & 0.025 & 0.008 & 0.032 \\
Regression with & $0.768^{*}$ & -1.102 & $(0.178)$ & $0.210^{*}$ & 0.079 & 0.034 \\
additional controls & $(0.386)$ & $(1.307)$ & $(0.133)$ & $(0.113)$ & $(0.111)$ & $(0.110)$ \\
N & 40 & 40 & 40 & 40 & 40 & 40 \\
R-Squared & 0.443 & 0.659 & 0.429 & 0.232 & 0.356 & 0.379 \\
\hline
\end{tabular}

Notes: (a) Coefficients describe the effects of SEWA service. Models (1) and (3) through (6) are linear probability model results, using Equation 6.1. Model (2) is the OLS regression using Equation 6.2; (b) Robust standard errors in parentheses; (c) 'Less Frequent Pump Breakdowns' takes the value 1 if on average a GWSSB in the village breaks down less than once a month and 0 if more than once a month. 'Number of Pump Breakdowns' are the actual number of breakdowns recorded over past 12 months. 'Pumps Repaired within ...' takes the value 1 if a broken pump gets repaired within the four time categories, 0 otherwise; (d) Baseline regression only includes one regressor that indicates whether or not a village is serviced by SEWA; (e) Regressions with additional controls also include: key informant's age, gender, education level and position in village; village population, village lowest household income, and whether the village has access to piped water or well water; ${ }^{*} \mathrm{p}<0.1, * * \mathrm{p}<0.05, \mathrm{p}<0.001 * * *$.

sources or resort to a pump that is located further away, which is also a significant cost. Our results indicate that service quality also influences the time spent collecting water. In particular, prompt handpump repair might significantly reduce the average time spent collecting water, in both the dry and wet seasons.

Our survey data do not allow us to decompose the observed effects of government-CSO co-management contracts into SEWA's organizational identity, managerial capacity, political capacity, or the individual technical capacity of SEWA's female technicians. However, we collected qualitative data on 15 SEWA female technicians regarding their motivations. ${ }^{10}$ When asked for reasons why they took up handpump repair work, they all cited 'service to women and society' as one of the reasons if not the primary reason. ${ }^{11}$ This resonates with earlier work by Siddiqi and Oever (1998) and Khanom (2012) in which they argue that government-CSO co-management contracts are able to deliver because CSO contractors are more connected 


\begin{tabular}{lll}
\hline & \multicolumn{2}{l}{ Person most responsible for collecting water } \\
\cline { 2 - 3 } & Dry Season & Wet Season \\
\cline { 2 - 3 } & $\mathbf{1}$ & $\mathbf{2}$ \\
\hline Baseline regression & $-0.417^{* * *}$ & $-0.305^{* * *}$ \\
& $(0.090)$ & $(0.062)$ \\
$\mathrm{N}$ & 200 & 200 \\
R-Squared & 0.100 & 0.158 \\
Regression with & $-0.275^{* * *}$ & $-0.235^{* * *}$ \\
additional controls & $(0.087)$ & $(0.063)$ \\
N & 200 & 200 \\
R-Squared & 0.408 & 0.415 \\
\hline
\end{tabular}

Notes: (a) Coefficients reported are effects of SEWA service using OLS regression in Equation 6.1; (b) Robust standard errors in parentheses; (c) Outcomes are measured in hours of time spent collecting water per day; (d) Baseline regression only includes one regressor that indicates whether or not a household is serviced by SEWA; (e) Regressions with additional controls also include: respondent age, gender, education level, household size, agriculture land size, caste of head of household, distance to the nearest GWSSB pump, whether household has alternative water sources, whether household owns an electric pump, village population, village lowest household income, and whether the village has access to pipe water or well; ${ }^{*} \mathrm{p}<0.1,{ }^{* *} \mathrm{p}<0.05$, $\mathrm{p}<0.001^{* * *}$.

with and have better knowledge of the needs and priorities of the communities they serve. We therefore interpret the differences between service provision of SEWA and non-SEWA contractors as a composite effect of government-CSO co-management contract on handpump repair services including unique motivations of the female technicians.

\section{CONCLUSION}

Using end-user household survey data collected in two sub-districts of Gujarat, we examine whether there are differences in the quality of services provided in maintaining and repairing community handpumps when the state water authority enters into co-management contracts with CSOs to provide repair services versus when services are contracted out to private organizations. We find that CSO repair contractors, trained by the Self-Employed Women's Association (SEWA) provide better quality service than non-SEWA contractors. Specifically, SEWA service significantly reduces time to collect water in both the dry and wet seasons and reduces the time to attend to pump breakdowns, thus further reducing the imposed cost of water collection. In addition, there is a significant reduction in repair time for handpumps used by lower caste households in SEWA serviced villages, suggesting that contracting out 
services to CSOs may indeed bring about equity in access to public goods and services.

Unlike previous studies in which measuring the cost of inadequate water infrastructure was limited to distance and the time taken to access water sources, we provide causal evidence suggesting that the quality of water service delivery also matters. As service quality may be correlated with village characteristics, we use exogenous variation generated by the Gujarat Water Supply and Sewerage Board (GWSSB) tendering process to examine this effect. Our findings also highlight the critical role played by community-based CSOs in improving the quality of handpump maintenance and repair. Clearly, the capacity of the actors involved in the co-management contracts matters and qualitative evidence suggests that both GWSSB and SEWA recognized their respective strengths and shortcomings and complemented each other. Our analysis provides a composite effect of government-CSO co-management contract on handpump repair services including motivations of CSO contractors.

From a public policy perspective, our findings imply that it is not only important to expand infrastructure to reduce the burden of collecting water on rural households, but equally important to ensure that the infrastructure is properly maintained through innovative government-CSO (or state-non-state) contractual relationships such as co-management. The GWSSB's efforts to contract out the maintenance and repair of village water handpumps to a CSO such as SEWA is a positive step in this direction.

\section{NOTES}

1. A shorter version of this chapter has appeared as a journal article in Policy Design and Practice (Chindarkar, Chen, and Wichelns 2018).

2. We thank Ms. Reema Nanavaty and Ms. Bharti Bhavsar from the Self-Employed Women's Association (SEWA) for providing us the opportunity to conduct this research. We thank Dennis Wichelns, Sonia Akter, and seminar audiences at the Lee Kuan Yew School of Public Policy Research Seminar for their helpful comments. We thank Ms. Shilpa Sathe for her excellent research assistance. The findings, interpretations, conclusions, and any errors are entirely those of the authors. We are grateful for the financial support offered by the Lee Kuan Yew School of Public Policy and the Institute of Water Policy at the National University of Singapore.

3. Specifically, the India Mark II and India Mark III handpump designs.

4. The four government-NGO relationship types are: partnerships (high mutuality, high identity), co-optation (high mutuality, low identity), contract (low mutuality, high identity), and extension (low mutuality, low identity) (Brinkerhoff 2002).

5. Information gathered through interviews with SEWA members and GWSSB officials.

6. Information gathered through interviews with SEWA members and GWSSB officials. 
7. Groundwater level observation wells are not located in individual sub-districts. Therefore, disaggregated groundwater level data are not available.

8. We could not obtain a list of non-SEWA contractors operating in the two sub-districts. However, in our qualitative information, we find no indication of the presence of NGO contractors other than SEWA.

9. We sampled the key informants by identifying the head of each village Panchayat and then interviewed one additional public servant based on his/her referral.

10. These 15 women consisted the sampling universe of the actively working SEWA technicians at the time of the survey.

11. We could not interview non-SEWA handpump repair contractors to corroborate the motivations. However, we posed the same question to other randomly selected women from the same villages as the SEWA contractors. These women were engaged in wage-earning activities such as farm labor and non-farm labor (other than handpump repair work). None of them referred to contribution to the larger community as a motivation for taking up wage work. 